\title{
Properties of saw-dust, paper and starch composite ceiling board Obam, Sylvester Ogah
}

\author{
Department of Civil Engineering; University of Agriculture Makurdi. \\ Email: ogahobam@yahoo.com
}

\begin{abstract}
Many organic waste materials such as saw-dust, paper etcetera, pose environmental nuisance. The cost of building materials is high and beyond the reach of many people in developing countries. In this paper, efforts have been made to convert saw-dust, waste paper and starch into the production of ceiling boards. This is done with a view to having alternative to the traditional asbestos ceiling boards that are costly and also pose health risks. Laboratory experimental procedures were used to determine the production of the composite. The composite sample boards were subjected to thermal conductivity test. It has an average value of $9.2 \times 10^{-2} \mathrm{~W} / \mathrm{mK}$. The flakeness test of the sample boards gave a mean value of $6.86 \times 10^{-3}$. About 8.6 per cent Water Absorption was discovered on the dry samples of the boards. The mean flexural strength of the boards is 0.05 $\mathrm{N} / \mathrm{mm}^{2}$. The composite boards were successfully nailed with firm grips. The boards show good potential as ceiling boards.
\end{abstract}

Keywords: Organic wastes, ceiling board, thermal conductivity, flexure.

\section{INTRODUCTION}

The famous religious Awake magazine, in 1990, stated that in USA, over 400,000 tons of wastes were disposed of every day, running into millions of dollars. In Nigeria, especially, urban areas like Lagos, Kano, Ibadan etc, all kinds of organic wastes such as polythene bags, paper, agricultural wastes, etc are common sight (1). The amount of solid waste per capita generated in developing countries has risen to about 20 tons per year (2). It is observed that $45-50$ per cent of original wood (timber) taken for mechanical processing ended in waste (3). Saw-dust is a major component of the waste. Cottage industries such as carpentry, saw-milling, felling of timbers etc, produce enormous saw-dust waste in Nigeria. It is estimated that the volume of saw-dust waste generated by saw-mills is about 3.89 million cubic meters per year (4). This waste generation increases with industrial growth.

Some of these wastes are burnt in open air, producing substances that pose health hazards. One of the ways of minimizing environmental nuisance and health risks pose by these wastes is to effectively recycle them. Rice husks, maize cub, waste paper, starch and cement were used to produce ceiling boards (1).
Ceiling boards are required in houses to reduce sound and heat and they give additional aesthetics. A ceiling with its upper surface highly reflective, having a good heat insulation and low thermal capacity is recommended in hot climates (5). As a performance standard, it is recommended that thermal conductivity of ceiling boards should be within $0.50-0.15 \mathrm{~W} / \mathrm{mK}$ (6).

Asbestos ceiling boards are fragile, pose health risks and relatively costly (7). Therefore, there is a compelling need to produce alternative products that are cheap, using local organic materials that could pose little or no health hazards.

Thermal conductivity is the ability of material to conduct heat (8). The thermal conductivity of light weight concrete varies with its density (9). Bricks and ceramics often contain tiny pores that could cause capillary action. Water absorption is the ratio of mass of water absorbed over the dry mass of material (10).

Flexural strength measures the ability of material to resist bending. Although, concrete is not normally designed to resist flexural stress, its knowledge helps in estimating the load under which cracks would develop (8).

\section{MATERIALS AND METHODS}

Paper: Waste papers were collected from schools and markets in Makurdi, Nigeria. Unwanted materials such as stencil papers, office pins, cenotaph, etc., 
were carefully removed manually from the sample papers. The papers are to serve as sources of fiber for the composite. The paper samples were shredded manually. They were then soaked in water at room temperature for about an hour. Water was drained out of the papers by manually squeezing them. They wet sample was then mashed in mortar with a pestle until it became smooth and soft.

Starch: Waste liquid got from raw cassava, in Gari (processed powdered cassava) processing factory, was collected in buckets. It was allowed to settle for about four hours and then decanted. The residue was dried in the oven at 100 degree Celsius to get the sample in powdered form, the starch. It serves as binder in the mixture.

Saw-dust: Saw-dust samples were collected from saw mill, timber shade, makurdi-Nigeria. The samples were dried in the open at room temperature. It was then sieved through $1.18 \mathrm{~mm}$ sieve. This was done to get rid of some unwanted materials such as polythene bags, pieces of metals and wood, etc. Saw-dust serves as both filler and source of fiber in the matrix.

Cement: The cement used in the mixture is ordinary Portland cement. It was purchased in Makurdi and used as supplied.

Water: Pipe-borne water supplied to the school of engineering, University of Agriculture Makurdi, Nigeria was used in the mixture.

The process for the production of ceiling boards: Saw-dust and cement were mixed at arbitrarily selected ratios. A known weight of the mashed waste paper and the starch were mixed. Selected ratios of Saw-dust and cement were mixed. The starch-paper mix was mixed with cement-sawdust mix in a bucket. It was stirred to a homogenous mix. A mould of size $300 \times 300 \mathrm{~mm}$ with a thickness of $8 \mathrm{~mm}$ was cleaned and oiled lightly with petroleum lubricant. The mix was then cast into the mould with manual compaction by hand and rod. A trowel was used to smoothing the exposed top surface. Twenty samples of the boards were produced. The boards were demoulded at the seventh day. Removing the moulds from the samples can be done as soon as the samples have gained enough strength to support themselves.

\section{Tests Carried Out on the Ceiling Board Samples}

Water absorption: The dry boards were weighed and immersed in water for 24 hours. They were allowed to surface-dry then weighed.
$\boldsymbol{p}=\frac{\left(W_{s}-W_{d}\right) 100}{W_{d}}$

$P$ is the percentage water absorption

$\mathrm{W}_{\mathrm{s}}$ of the surface-dry sample

$\mathrm{W}_{\mathrm{d}}$ dry sample

Thermal conductivity: The composite was cast to size $400 \mathrm{~mm} \times 400 \mathrm{~mm}$ and thickness $3 \mathrm{~mm}$. A hardened sample was placed between hot and cold surfaces of thermal conductivity test machine. The hot surface was heated while cold water was made to pass through the cold surface continuously through out the period of heating. The temperatures at the hot surface $\left(T_{1}\right)$ and cold surface $\left(T_{2}\right)$ were noted as soon as steady temperature readings were observed. The thermal flux (p) was noted in the electric power of the heater.

$K=\frac{p t}{A\left(T_{1}-T_{2}\right)}$

$\mathrm{K}$ is thermal conductivity

Flexural strength: The composite was cast to size $100 \times 100 \times 500 \mathrm{~mm}$ sample beam. The hardened samples were subjected to flexural (bending) stress according to BS 1881: part 118, 1983 (11). Flexural stress is given by

$\sigma_{f}=\frac{p l}{b d^{2}}$

$p$ is the maximum load on the beam

I is the span of beam

$b$ is the width of the beam

$d$ is the depth of the beam

Flaking test: A dried sample board was weighed $\left(\mathrm{W}_{1}\right)$. A hard shoe brush was used to rub against the two surfaces of the board. 50 strokes of forward and backward movements each were made against the surfaces. The flaked particles from the surfaces were collected and weighed. The flaked board was also weighed $\left(\mathrm{W}_{2}\right)$. This procedure was repeated for nine more samples. Flaking concentration $\left(F_{c}\right)$ is given by

$F_{c}=\frac{W_{1}-W_{2}}{W_{1}}$

\section{RESULTS AND ANALYSIS}

The results of water absorption are shown in table 1 
Am. J. Sci. Ind. Res., 2012, 3(5): 300-304

Table 1. Water absorption of the board samples

\begin{tabular}{|l|l|l|l|}
\hline Sample No. & $\begin{array}{l}\text { Dry weight of sample } \\
(\mathrm{Kg})\end{array}$ & $\begin{array}{l}\text { Weight of surface-dry } \\
\text { sample }(\mathrm{Kg})\end{array}$ & $\begin{array}{l}\text { Percentage } \\
\text { absorption }\end{array}$ \\
\hline 1 & 5.28 & 5.62 & 6.0 \\
\hline 2 & 5.32 & 5.81 & 9.0 \\
\hline 3 & 5.30 & 5.86 & 11.0 \\
\hline 4 & 5.29 & 5.70 & 8.0 \\
\hline 5 & 5.30 & 5.86 & 10.0 \\
\hline 6 & 5.31 & 5.69 & 7.0 \\
\hline 7 & 5.30 & 5.80 & 9.0 \\
\hline 8 & 5.32 & 5.77 & 9.0 \\
\hline 9 & 5.30 & 5.82 & 10.0 \\
\hline 10 & 5.33 & 5.68 & 7.0 \\
\hline & & Mean & 8.6 \\
\cline { 2 - 4 } & & &
\end{tabular}

Table 2. Results of Thermal conductivity Tests

\begin{tabular}{|c|c|c|c|c|c|c|c|}
\hline $\begin{array}{l}\text { Sample } \\
\text { No. }\end{array}$ & $\begin{array}{l}\text { Time } \\
\text { (s) }\end{array}$ & $\begin{array}{l}\text { Power } \\
\text { (watt) }\end{array}$ & $\begin{array}{l}\mathrm{T}_{1} \\
\text { (Kelvin) }\end{array}$ & $\begin{array}{l}\mathrm{T}_{2} \\
\text { (Kelvin) }\end{array}$ & $\begin{array}{l}\Delta_{T} \\
\text { (Kelvin) }\end{array}$ & $\begin{array}{l}\mathrm{K} \\
(\mathrm{kw} / \mathrm{mK})\end{array}$ & $\begin{array}{l}\text { Mean } \\
\text { Value }(\mathrm{kw} / \mathrm{mK})\end{array}$ \\
\hline \multirow[t]{2}{*}{1} & 1800 & 472 & 21 & 131 & 383.15 & 0.092 & \multirow[t]{2}{*}{\begin{tabular}{|l|l}
0.092 \\
\end{tabular}} \\
\hline & 3600 & 472 & 20 & 130 & 383.15 & 0.092 & \\
\hline \multirow[t]{2}{*}{2} & 1800 & 472 & 18 & 129 & 384.15 & 0.092 & \multirow[t]{2}{*}{0.092} \\
\hline & 3600 & 472 & 19 & 130 & 384.15 & 0.092 & \\
\hline \multirow[t]{2}{*}{3} & 3600 & 472 & 20 & 130 & 383.15 & 0.092 & \multirow[t]{2}{*}{0.092} \\
\hline & 5400 & 472 & 21 & 131 & 383.15 & 0.092 & \\
\hline \multirow[t]{2}{*}{4} & 1800 & 472 & 20 & 130 & 383.15 & 0.092 & \multirow[t]{2}{*}{0.093} \\
\hline & 3600 & 472 & 20 & 130 & 382.65 & 0.093 & \\
\hline \multirow[t]{2}{*}{5} & 3600 & 472 & 21 & 131 & 383.15 & 0.092 & \multirow[t]{2}{*}{0.093} \\
\hline & 5400 & 472 & 22 & 130 & 381.65 & 0.093 & \\
\hline
\end{tabular}

The average water absorption of the boards is about 8.6 percent. This value is relatively low. Asbestos board, an inorganic material, has water absorption of about 0.5 percent. Organic materials generally absorb water readily.
Thermal Conductivity: The sample boards have an average thermal conductivity of 0.092 . Asbestos have thermal conductivity value of about 0.096 (7). Hence, the saw-dust paper board has greater insulating properties and shows good potential to be used as ceiling board. 
Table 2. Results of Thermal conductivity Tests Continues

\begin{tabular}{|c|c|c|c|c|c|c|c|}
\hline $\begin{array}{l}\text { Sample } \\
\text { No. }\end{array}$ & $\begin{array}{l}\text { Time } \\
\text { (s) }\end{array}$ & $\begin{array}{l}\text { Power } \\
\text { (watt) }\end{array}$ & $\begin{array}{l}\mathrm{T}_{1} \\
\text { (Kelvin) }\end{array}$ & $\begin{array}{l}\mathrm{T}_{2} \\
\text { (Kelvin) }\end{array}$ & $\begin{array}{l}\Delta_{T} \\
\text { (Kelvin) }\end{array}$ & $\begin{array}{l}\mathrm{K} \\
(\mathrm{kw} / \mathrm{mK})\end{array}$ & $\begin{array}{l}\text { Mean } \\
\text { Value }(\mathrm{kw} / \mathrm{mK})\end{array}$ \\
\hline \multirow[t]{2}{*}{6} & 1800 & 472 & 20 & 131 & 384.15 & 0.092 & \multirow[t]{2}{*}{0.092} \\
\hline & 3600 & 472 & 20 & 130 & 383.15 & 0.092 & \\
\hline \multirow[t]{2}{*}{7} & 3600 & 472 & 20 & 130 & 383.15 & 0.092 & \multirow[t]{2}{*}{0.093} \\
\hline & 5400 & 472 & 21 & 130 & 381.65 & 0.093 & \\
\hline \multirow[t]{2}{*}{8} & 1800 & 472 & 21 & 131 & 383.15 & 0.092 & \multirow[t]{2}{*}{0.092} \\
\hline & 5400 & 472 & 21 & 131 & 3383.15 & 0.092 & \\
\hline \multirow[t]{2}{*}{9} & 1800 & 472 & 19 & 129 & 383.15 & 0.092 & \multirow[t]{2}{*}{0.092} \\
\hline & 3600 & 472 & 20 & 130 & 383.15 & 0.092 & \\
\hline \multirow[t]{2}{*}{10} & 1800 & 472 & 20 & 130 & 383.15 & 0.092 & \multirow[t]{2}{*}{0.092} \\
\hline & 3600 & 472 & 21 & 131 & 383.65 & 0.092 & \\
\hline
\end{tabular}

Flexural Strength: The results of flexural strength tests are shown in table 3.

Table 3. The results of flexural strength tests

\begin{tabular}{|l|l|l|}
\hline $\begin{array}{l}\text { Sample } \\
\text { No. }\end{array}$ & $\begin{array}{l}\text { Max. load } \\
(\mathbf{N})\end{array}$ & $\begin{array}{l}\text { Flexural stress } \\
\left(\mathbf{N} / \mathbf{m m}^{2}\right)\end{array}$ \\
\hline 1 & 78.5 & 0.04 \\
\hline 2 & 98.1 & 0.05 \\
\hline 3 & 82.4 & 0.04 \\
\hline 4 & 108.9 & 0.05 \\
\hline 5 & 106.0 & 0.05 \\
\hline 6 & 113.8 & 0.06 \\
\hline 7 & 113.8 & 0.06 \\
\hline 8 & 113.5 & 0.06 \\
\hline 9 & 117.7 & 0.06 \\
\hline 10 & 117.0 & 0.06 \\
\hline Mean & & 0.05 \\
\cline { 3 - 3 } & &
\end{tabular}

The mean flexural strength of $0.05 \mathrm{~N} / \mathrm{mm}^{2}$ indicates a fragile board. Asbestos board has average flexural stress of about $1.00 \mathrm{~N} / \mathrm{mm}^{2}$ (7). Hence, it is obviously less fragile than saw-dust paper board.

Flaking Test: The results of flaking tests of the boards are shown in table 4 .

Table 4. The results of flaking tests of the boards

\begin{tabular}{|l|l|l|l|l|}
\hline $\begin{array}{l}\text { Sample } \\
\text { No. }\end{array}$ & $\mathbf{W}_{\mathbf{1}} \mathbf{( g )}$ & $\begin{array}{l}\mathbf{W}_{\mathbf{2}} \\
\mathbf{( g )}\end{array}$ & $\mathbf{W}_{\mathbf{3}} \mathbf{( g )}$ & $\mathbf{F}_{\mathbf{c}}\left(\mathbf{x} \mathbf{1 0}^{-}\right.$ \\
\hline 1 & 554.0 & 3.8 & 550.2 & 6.86 \\
\hline 2 & 554.5 & 3.5 & 551.0 & 6.31 \\
\hline 3 & 555.0 & 4.2 & 550.8 & 7.57 \\
\hline
\end{tabular}

\begin{tabular}{|l|l|l|l|l|}
\hline 4 & 554.2 & 4.1 & 550.1 & 7.40 \\
\hline 5 & 554.2 & 3.8 & 550.4 & 6.86 \\
\hline 6 & 555.1 & 3.9 & 551.2 & 7.03 \\
\hline 7 & 554.8 & 4.2 & 550.6 & 7.70 \\
\hline 8 & 554.6 & 4.4 & 550.2 & 7.90 \\
\hline 9 & 554.0 & 3.6 & 550.4 & 6.50 \\
\hline 10 & 554.4 & 4.3 & 550.1 & 7.76 \\
\hline Mean & \multicolumn{3}{|l}{} & 7.20 \\
\hline
\end{tabular}

\section{Legend:}

$\mathrm{W}_{1}$ is weight of sample

$W_{2}$ is weight of flaked particles

$\mathrm{W}_{3}$ is weight of sample after flaking

$\mathrm{T}_{1}$ is temperature of cold surface

$\mathrm{T}_{2}$ is temperature of hot surface

$\Delta_{\mathrm{T}}$ is temperature gradient

$\mathrm{K}$ is thermal conductivity

The results from table 4 show a low flake concentration when compared with asbestos boards whose value is about $2.0 \times 10^{-2}(7)$.

Nailing of the Boards: Carpenter harmer was used to drive a $3 \mathrm{~mm}$ nail into the board. This was repeated

for nine more boards. After three blows the boards showed no sign of cracks visible to my eyes and nail half driven in. The nail was fully pushed in and tiny cracks visible to my eyes developed but the nail was held firmly in the board.

Therefore, the boards could be nailed successfully. 
Conclusion and recommendations: The ever increasing cost of building materials makes the search for cheap ones non optional. In Nigeria and many other developing countries, asbestos products are dominant in the building industry, with its health hazards. In this paper efforts have been made to convert saw-dust, waste paper and starch into the production of ceiling boards. The composite sample boards were subjected to thermal conductivity test. It has an average value of $9.2 \times 10^{-2}$ $\mathrm{W} / \mathrm{mK}$. The flakeness test of the sample boards gave a mean value of $6.86 \times 10^{-3}$. About 8.6 per cent Water Absorption was discovered on the dry samples of the boards. The mean flexural strength of the boards is $0.05 \mathrm{~N} / \mathrm{mm}^{2}$. The composite boards were successfully nailed with firm grips. The boards show good potential as ceiling boards.

The composite boards need to be impregnated with bituminous materials to reduce its water absorption or permeability. The commercial production of the board can be mechanized to enhance its properties. Nails could be substituted with bolts and rivets when fixing the boards.

\section{REFERNCES}

Ebeh, S. E., (1997); Recycling of solid domestic and agricultural wastes for use in building industry as alternative to asbestos ceiling boards; thesis, University of Agriculture Makurdi
Jorgenson, S. E. and Johnson, I., (1989); Principle of Environmental Science and Engineering, Bombay

Badejo, S. O., (2001); Saw-dust utilization for building materials production in Nigeria-Technical report, No. 50 , forestry research institute of Nigeria, Ibadan

Badejo, S. O. and Giwa, S. A., (1985); Volume assessment and economic importance of wood wastes utilization in Nigeria- Technical report, No. 50 , forestry research institute of Nigeria, Ibadan

Saini, B. S., (1980); Building in Hot, Dry Climate, Toronto; 384-396

Charles, T. L., (1989); Practical Handbook of Material Science; CRC Press Inc. Florida

Berge, H., (1963); Asbestos Fundamentals, Origin and Properties; McGraw-Hill, London

Neville, A. M., (1997); Properties of Concrete; Longman Ltd. England

Davey, N., (1994); Concrete mixes for various building purposes; cement and Concrete Association, London; 28-41

Jackson, N. (1984); Civil Engineering Materials; Macmillan Ltd. London; 386-387

British Standard (BS) 1881: part 118 (1983); Method of determination of flexural strength 